\title{
The Evolution and Variability of Atmospheric Ozone over Geological Time
}

\author{
JOEL S. LEVINE \\ Atmospheric Environmental Sciences Division, NASA Langley Research Center, Hampton, Virginia 23665 \\ PAUL B. HAYS \\ Department of Atmospheric and Oceanic Science, The University of Michigan, Ann Arbor, Michigan 48109
}

AND

JAMES C. G. WALKER

Arecibo Observatory, National Astronomy and Ionosphere Center, Arecibo, Puerto Rico 00612

Received November 27, 1978; revised April 11, 1979

\begin{abstract}
The rise of atmospheric $\mathrm{O}_{3}$ as a function of the evolution of $\mathrm{O}_{2}$ has been investigated using a one-dimensional steady-state photochemical model based on the chemistry and photochemistry of $\mathrm{O}_{x}\left(\mathrm{O}_{3}, \mathrm{O}, \mathrm{O}\left({ }^{\mathrm{D} D}\right)\right), \mathrm{N}_{2} \mathrm{O}, \mathrm{NO}_{x}\left(\mathrm{NO}, \mathrm{NO}_{2}, \mathrm{HNO}_{3}\right), \mathrm{H}_{2} \mathrm{O}$, and $\mathrm{HO}_{x}\left(\mathrm{H}, \mathrm{OH}, \mathrm{HO}_{2}, \mathrm{H}_{2} \mathrm{O}_{2}\right)$ including the effect of vertical eddy transport on the species distribution. The total $\mathrm{O}_{3}$ column density was found to maximize for an $\mathrm{O}_{2}$ level of $10^{-1}$ present atmospheric level (PAL) and exceeded the present total $\mathrm{O}_{3}$ column by about $40 \%$. For that level of $\mathrm{O}_{2}$, surface and tropospheric $\mathrm{O}_{3}$ densities exceeded those of the present atmosphere by about an order of magnitude. Surface and tropospheric OH densities of the paleoatmosphere exceeded those of the present atmosphere by orders of magnitude. We also found that in the $\mathrm{O}_{2}$-deficient paleoatmosphere, $\mathrm{N}_{2} \mathrm{O}$ (even at present atmospheric levels) produces much less $\mathrm{NO}_{x}$ than it does in the present atmosphere.
\end{abstract}

\section{INTRODUCTION}

By virtue of its very efficient shielding of the Earth's surface from lethal solar ultraviolet radiation, the evolution and natural variability of atmospheric ozone $\left(\mathrm{O}_{3}\right)$ over geological time were important factors in biological evolution on our planet (Berkner and Marshall, 1965; Ratner and Walker, 1972; and Walker, 1977). The appearance and evolution of $\mathrm{O}_{3}$ were strongly coupled to the appearance and evolution of molecular oxygen $\left(\mathrm{O}_{2}\right)$. The first investigation of the evolution of $\mathrm{O}_{3}$ in the $\mathrm{O}_{2}$ deficient paleoatmosphere was the qualitative treatment of Berkner and Marshall (1965). Next, Ratner and Walker (1972) used a simple photochemical model-the four Chapman reactions for a pure $\mathrm{O}_{2}$ atmosphere, without transport-to investigate the evolution of $\mathrm{O}_{3}$. Hesstvedt et al. (1974) added the hydrogen species chemistry to the Chapman reactions in their study. More recently, Blake and Carver (1977) added the nitrogen species chemistry (with the exception of nitrous oxide) to the hydrogen and oxygen species chemistry in a study of the evolution of $\mathrm{O}_{3}$. Blake and Carver (1977) assumed photochemical equilibrium, i.e., they did not include the effect of vertical transport on species distribution in their calculations. In the present study, we have included the chemistry of the oxygen, hydrogen, and nitrogen species, plus the effect of vertical transport on the distribution of the calculated atmospheric species. The present study is the first to include nitrous oxide $\left(\mathrm{N}_{2} \mathrm{O}\right)$ which is produced via dentrification by soil bacteria (Bates and Hays, 1967; Crutzen, 1970; McElroy and McConnell, 1971). The oxidation of $\mathrm{N}_{2} \mathrm{O}$ is the 295 
major source of the nitrogen oxides which control $\mathrm{O}_{3}$ levels in the present stratosphere (Crutzen, 1970). In addition, the present paper is the first to discuss the nitrogen and hydrogen species concentrations of the $\mathrm{O}_{2}-$ deficient paleoatmosphere and the variation of these species as $\mathrm{O}_{2}$ evolved to present atmospheric levels. The oxygen, nitrogen, and hydrogen reactions and rate constants used in the present study are based on those recommended in the recent NASA chlorofluoromethane-ozone assessment (Hudson, 1977). A description of the photochemical model used in this study is given in the appendix.

\section{COMPOSITION AND STRUCTURE OF THE PALEOATMOSPHERE}

One uncertainty in our study of the evolution of $\mathrm{O}_{3}$ as a function of evolving $\mathrm{O}_{2}$ level concerns the composition and structure of the paleoatmosphere during the period that $\mathrm{O}_{2}$ rose from $10^{-4}$ of its present atmospheric level $\left(10^{-4} \mathrm{PAL}\right)$ to its present atmospheric level (1 PAL). This uncertainty results in part from our lack of knowledge concerning the exact chronology for the evolution of $\mathrm{O}_{2}$. For example, Berkner and Marshall (1965) have speculated that $\mathrm{O}_{2}$ rose from $10^{-3}$ PAL to its present level in the more recent past, over the last 600 million years, whereas Walker (1978) has suggested that $\mathrm{O}_{2}$ rose rapidly from essentially zero to within a factor of 10 of its present atmospheric value as early as about 2 billion years ago. For our photochemical calculations we need to know the approximate concentrations of nitrogen $\left(\mathrm{N}_{2}\right)$, water vapor $\left(\mathrm{H}_{2} \mathrm{O}\right)$, carbon dioxide $\left(\mathrm{CO}_{2}\right)$, and reduced species such as methane $\left(\mathrm{CH}_{4}\right)$ and ammonia $\left(\mathrm{NH}_{3}\right)$ in the paleoatmosphere as $\mathrm{O}_{2}$ evolved from $10^{-4}$ PAL to its present level. Our information concerning the chemical composition of the paleoatmosphere during the evolution of $\mathrm{O}_{2}$ is based on two recent studies: a detailed review of the available geological and paleontological evidence by Walker (1977) and a computer simulation of the chemical evolution of the atmosphere by Hart (1978). Walker concluded that the atmosphere formed via volatile outgassing very early in the Earth's history and that the paleoatmosphere contained about as much $\mathrm{N}_{2}, \mathrm{H}_{2} \mathrm{O}$, and $\mathrm{CO}_{2}$ as the present atmosphere. Hart's computer simulation developed the following scenario: the $\mathrm{O}_{2}$ released from the photodissociation of $\mathrm{H}_{2} \mathrm{O}$ and from photosynthesis (after the first $\mathbf{8 0 0}$ million years) chemically destroyed the $\mathrm{CH}_{4}$ and $\mathrm{NH}_{3}$ in the paleoatmosphere. By roughly 2 billion years ago, all but the trace amounts of reduced gases had been removed from the atmosphere and at that point the atmosphere consisted primarily of $\mathrm{N}_{2}$ (about $96 \%$ ). Hart's calculations indicate that both $\mathrm{CH}_{4}$ and $\mathrm{NH}_{3}$ reached their present atmospheric levels about 2 billion years ago. The studies of Walker and Hart suggest that during the evolution of $\mathrm{O}_{2}$ and $\mathrm{O}_{3}$ the chemical composition of the paleoatmosphere was similar to the composition of the present atmosphere. Due to the assumed similarity (with the exception of $\mathrm{O}_{2}$ and $\mathrm{O}_{3}$ ) in the composition of the paleoatmosphere and the modern atmosphere, we have adopted the $\mathrm{O}_{3}$ photochemical and chemical reactions used in the current investigations of possible inadvertent depletion of $\mathrm{O}_{3}$ due to anthropogenic activities (Hudson, 1977). The chemistry of $\mathrm{CH}_{4}, \mathrm{NH}_{3}, \mathrm{CO}_{2}, \mathrm{CO}$, and the chlorine species is not included in our calculations. The photochemical and chemical reactions used in our model are listed in Tables I and II.

To calculate the photodissociation rates of the molecular species given in Table I, the solar spectrum between 110 and $735 \mathrm{~nm}$ was divided into 174 spectral intervals, with molecular cross sections for each species folded into these spectral intervals. The solar flux data are from Ackerman (1971). The species absorption cross-section references are also given in Table I. The calculations of the transmittance and rate of dissociation of molecular oxygen in the Schumann-Runge band (19 spectral intervals between 175 and $205 \mathrm{~nm}$ ) are based on 
TABLE I

Photochemical Reactions

\begin{tabular}{|c|c|c|}
\hline No. & $\begin{array}{l}\text { Photochemical reaction } \\
\qquad\left(\sec ^{-1}\right)\end{array}$ & $\begin{array}{l}\text { References for } \\
\text { cross sections }\end{array}$ \\
\hline $\mathbf{J} \mathbf{1}$ & $\mathrm{O}_{2}+h \nu(110-175 \mathrm{~nm}) \rightarrow \mathrm{O}+\mathrm{O}\left({ }^{1} \mathrm{D}\right)$ & Ackerman (1971); Watanabe (1958) \\
\hline $\mathbf{J} 2$ & $\mathrm{O}_{2}+h \nu(175-205 \mathrm{~nm}) \rightarrow \mathrm{O}+\mathrm{O}$ & Hudson and Mahle (1972) \\
\hline J3 & $\mathrm{O}_{2}+h \nu(205-242 \mathrm{~nm}) \rightarrow \mathrm{O}+\mathrm{O}$ & $\begin{array}{l}\text { Ackerman (1971); Hasson and } \\
\text { Nicholls (1971) }\end{array}$ \\
\hline $\mathrm{J} 4$ & $\mathrm{O}_{3}+h \nu(110-310 \mathrm{~nm}) \rightarrow \mathrm{O}_{2}\left({ }^{1} \Delta g\right)+\mathrm{O}\left({ }^{1} \mathrm{D}\right)$ & $\begin{array}{l}\text { Ackerman (1971); Inn and } \\
\text { Tanaka (1953) }\end{array}$ \\
\hline $\mathrm{J} 5$ & $\mathrm{O}_{3}+h \nu(310-360 \mathrm{~nm}) \rightarrow \mathrm{O}_{2}\left({ }^{1} \Delta g\right)+\mathrm{O}$ & $\begin{array}{l}\text { Ackerman (1971); Inn and } \\
\text { Tanaka (1953); Griggs (1968) }\end{array}$ \\
\hline J6 & $\mathrm{O}_{3}+h \nu(360-735 \mathrm{~nm}) \rightarrow \mathrm{O}_{2}+\mathrm{O}$ & $\begin{array}{l}\text { Ackerman (1971); Inn and } \\
\text { Tanaka (1953) }\end{array}$ \\
\hline J7 & $\mathrm{H}_{2} \mathrm{O}+h \nu(110-200 \mathrm{~nm}) \rightarrow \mathrm{OH}+\mathrm{H}$ & Watanabe and Zelikoff (1953) \\
\hline J8 & $\mathrm{N}_{2} \mathrm{O}+h \nu(110-315 \mathrm{~nm}) \rightarrow \mathrm{N}_{2}+\mathrm{O}\left({ }^{1} \mathrm{D}\right)$ & $\begin{array}{l}\text { Bates and Hays (1967); Johnston } \\
\text { and Selwyn (1975) }\end{array}$ \\
\hline J9 & $\mathrm{HNO}_{3}+h \nu(110-240 \mathrm{~nm}) \rightarrow \mathrm{H}+\mathrm{NO}_{3}$ & $\begin{array}{l}\text { Johnston and Graham (1974); } \\
\text { Schmidt, et al. (1974) }\end{array}$ \\
\hline $\mathbf{J} 10$ & $\mathrm{HNO}_{3}+h \nu(240-325 \mathrm{~nm}) \rightarrow \mathrm{OH}+\mathrm{NO}_{2}$ & $\begin{array}{l}\text { Johnston and Graham (1974); } \\
\text { Schmidt et al. (1974) }\end{array}$ \\
\hline $\mathbf{J} 11$ & $\mathrm{NO}_{2}+h \nu(110-245 \mathrm{~nm}) \rightarrow \mathrm{NO}+\mathrm{O}\left({ }^{\prime} \mathrm{D}\right)$ & $\begin{array}{l}\text { Dixon (1940); Hall and Blacet } \\
\text { (1952); Nakayama et al. (1959) }\end{array}$ \\
\hline $\mathrm{J} 12$ & $\mathrm{NO}_{2}+h \nu(245-398 \mathrm{~nm}) \rightarrow \mathrm{NO}+\mathrm{O}$ & $\begin{array}{l}\text { Dixon (1940); Hall and Blacet } \\
\quad(1952) ; \text { Nakayama et al. (1959) }\end{array}$ \\
\hline $\mathbf{J} 13$ & $\mathrm{H}_{2} \mathrm{O}_{2}+h \nu(110-370 \mathrm{~nm}) \rightarrow \mathrm{OH}+\mathrm{OH}$ & $\begin{array}{l}\text { Schürgers and Welge (1968); } \\
\text { Paukert and Johnston (1972) }\end{array}$ \\
\hline
\end{tabular}

the data of Hudson and Mahle (1972). The Hudson and Mahle data include the values of band oscillator strengths and rotational linewidths for the Schumann-Runge band system from which the transmittance and rate of dissociation of molecular oxygen as functions of temperature and oxygen column density have been calculated. For all the photodissociation rates, the incident solar flux is attenuated by $\mathrm{O}_{2}, \mathrm{O}_{3}, \mathrm{H}_{2} \mathrm{O}$, $\mathrm{CO}_{2}$, and $\mathrm{CH}_{4}$ absorption and is calculated in 1-km altitude intervals between the surface and $80 \mathrm{~km}$. All of the photodissociation calculations are diurnal averages for a specified latitude and solar declination based on the procedure of Rundel (1977). Unless otherwise noted, all of the calculations in this paper are for a latitude of $30^{\circ}$ and for a solar declination of $0^{\circ}$ (equinoctial conditions).

In the model, the following species profiles are calculated using a timeindependent or steady-state species con- tinuity equation, which combines the effects of both chemistry and vertical eddy transport: $\mathrm{O}_{3}$, nitrous oxide $\left(\mathrm{N}_{2} \mathrm{O}\right)$, and the odd nitrogen species $\left(\mathrm{NO}_{x}\right)$, which we define as the sum of nitric oxide (NO), nitrogen dioxide $\left(\mathrm{NO}_{2}\right)$, and nitric acid $\left(\mathrm{HNO}_{3}\right)$. The vertical distribution of the rapidly reacting atmospheric species $(O$, $\mathrm{O}\left({ }^{1} \mathrm{D}\right), \mathrm{H}, \mathrm{OH}, \mathrm{HO}_{2}$, and $\mathrm{H}_{2} \mathrm{O}_{2}$ ) is determined solely by chemistry, which for these species is considerably faster than transport. The production and loss terms for all of the species are summarized in the Appendix. The vertical distribution of the following species are specified as input parameters: $\mathrm{H}_{2} \mathrm{O}$ (London and Park, 1974), $\mathrm{CO}_{2}$ (Stewart and Hoffert, 1975), and $\mathrm{CH}_{4}$ (Wofsy, 1976; Liu and Donahue, 1974).

In the present atmosphere the $\mathrm{H}_{2} \mathrm{O}$ vapor mixing ratio above the tropopause is controlled by the tropopause temperature-the so-called "cold trap." A tenfold increase in the $\mathrm{H}_{2} \mathrm{O}$ vapor mixing ratio above the 
TABLE II

Chemical Reactions

\begin{tabular}{|c|c|c|c|}
\hline No. & Reaction & $\begin{array}{c}\text { Rate constant } \\
\left(\mathrm{cm}^{3} \mathrm{sec}^{-1} \text { or } \mathrm{cm}^{6} \mathrm{sec}^{-1}\right)\end{array}$ & Reference \\
\hline 1 & $\mathrm{O}+\mathrm{O}_{2}+\mathbf{M} \rightarrow \mathrm{O}_{3}+\mathrm{M}$ & $1.1 \times 10^{-34} \exp (510 / T)$ & Huie et al. (1972) \\
\hline 2 & $\mathrm{O}+\mathrm{O}_{3} \rightarrow 2 \mathrm{O}_{2}$ & $1.9 \times 10^{-11} \exp (-2300 / T)$ & CIAP Monograph I (1974) \\
\hline 3 & $\mathrm{O}\left({ }^{1} \mathrm{D}\right)+\mathrm{O}_{3} \rightarrow 2 \mathrm{O}_{2}$ & $1.2 \times 10^{-10}$ & Hudson (1977) \\
\hline 4 & $\left.O{ }^{(} D\right)+M \rightarrow O+M$ & $2.0 \times 10^{-11} \exp (107 / T)$ & Hudson (1977) \\
\hline 5 & $\mathrm{~N}_{2} \mathrm{O}+\mathrm{O}\left({ }^{1} \mathrm{D}\right) \rightarrow 2 \mathrm{NO}$ & $5.5 \times 10^{-11}$ & Hudson (1977) \\
\hline 6 & $\mathrm{~N}_{2} \mathrm{O}+\mathrm{O}\left({ }^{1} \mathrm{D}\right) \rightarrow \mathrm{N}_{2}+\mathrm{O}_{2}$ & $5.5 \times 10^{-11}$ & Hudson (1977) \\
\hline 7 & $\mathrm{NO}+\mathrm{O}+\mathrm{M} \rightarrow \mathrm{NO}_{2}+\mathrm{M}$ & $1.55 \times 10^{-32} \exp (584 / T)$ & Hudson (1977) \\
\hline 8 & $\mathrm{NO}+\mathrm{O}_{3} \rightarrow \mathrm{NO}_{2}+\mathrm{O}_{2}$ & $2.1 \times 10^{-12} \exp (-1450 / T)$ & Hudson (1977) \\
\hline 9 & $\mathrm{NO}_{2}+\mathrm{O} \rightarrow \mathrm{O}_{2}+\mathrm{NO}$ & $9.1 \times 10^{-12}$ & Hudson (1977) \\
\hline 10 & $\mathrm{NO}_{2}+\mathrm{O}_{3} \rightarrow \mathrm{NO}_{3}+\mathrm{O}_{2}$ & $1.2 \times 10^{-13} \exp (-2450 / T)$ & Hudson (1977) \\
\hline 11 & $\mathrm{NO}+\mathrm{HO}_{2} \rightarrow \mathrm{NO}_{2}+\mathrm{OH}$ & $8 \times 10^{-12}$ & Hudson (1977) \\
\hline 12 & $\mathrm{NO}_{2}+\mathrm{OH}+\mathrm{M} \rightarrow \mathrm{HNO}_{3}+\mathrm{M}$ & $\begin{array}{l}2.76 \times 10^{-13} \exp (880 / T) / \\
\quad\left(1.17 \times 10^{18} \exp \{222 / T+[\mathrm{M}]\}\right)\end{array}$ & Hudson (1977) \\
\hline 13 & $\mathrm{HNO}_{3}+\mathrm{OH} \rightarrow \mathrm{NO}_{3}+\mathrm{H}_{2} \mathrm{O}$ & $8 \times 10^{-14}$ & Hudson (1977) \\
\hline 14 & $\mathrm{H}_{2} \mathrm{O}+\mathrm{O}\left({ }^{1} \mathrm{D}\right) \rightarrow 2 \mathrm{OH}$ & $2.3 \times 10^{-10}$ & Hudson (1977) \\
\hline 15 & $\mathrm{H}+\mathrm{O}_{2}+\mathrm{M} \rightarrow \mathrm{HO}_{2}+\mathrm{M}$ & $2.1 \times 10^{-32} \exp (290 / T)$ & Hudson (1977) \\
\hline 16 & $\mathrm{H}+\mathrm{O}_{3} \rightarrow \mathrm{OH}+\mathrm{O}_{2}$ & $1.2 \times 10^{-10} \exp (-560 / T)$ & Hudson (1977) \\
\hline 17 & $\mathrm{OH}+\mathrm{O} \rightarrow \mathrm{H}+\mathrm{O}_{2}$ & $4.2 \times 10^{-11}$ & Hudson (1977) \\
\hline 18 & $\mathrm{OH}+\mathrm{O}_{3} \rightarrow \mathrm{HO}_{2}+\mathrm{O}_{2}$ & $1.5 \times 10^{-12} \exp (-1000 / T)$ & Hudson (1977) \\
\hline 19 & $\mathrm{OH}+\mathrm{OH} \rightarrow \mathrm{H}_{2} \mathrm{O}+\mathrm{O}$ & $1 \times 10^{-11} \exp (-550 / T)$ & Hudson (1977) \\
\hline 20 & $\mathrm{HO}_{2}+\mathrm{O} \rightarrow \mathrm{OH}+\mathrm{O}_{2}$ & $3.5 \times 10^{-11}$ & Hudson (1977) \\
\hline 21 & $\mathrm{HO}_{2}+\mathrm{O}_{3} \rightarrow \mathrm{OH}+2 \mathrm{O}_{2}$ & $7.3 \times 10^{-14} \exp (-1275 / T)$ & Hudson (1977) \\
\hline 22 & $\mathrm{HO}_{2}+\mathrm{OH} \rightarrow \mathrm{H}_{2} \mathrm{O}+\mathrm{O}_{2}$ & $3 \times 10^{-11}$ & Hudson (1977) \\
\hline 23 & $\mathrm{HO}_{2}+\mathrm{HO}_{2} \rightarrow \mathrm{H}_{2} \mathrm{O}_{2}+\mathrm{O}_{2}$ & $2.5 \times 10^{-12}$ & Hudson (1977) \\
\hline 24 & $\mathrm{H}_{2} \mathrm{O}_{2}+\mathrm{OH} \rightarrow \mathrm{HO}_{2}+\mathrm{H}_{2} \mathrm{O}$ & $1 \times 10^{-11} \exp (-750 / T)$ & Hudson (1977) \\
\hline 25 & $\mathrm{H}_{2} \mathrm{O}_{2}+\mathrm{O} \rightarrow \mathrm{OH}+\mathrm{HO}_{2}$ & $2.75 \times 10^{-12} \exp (-2125 / T)$ & Hudson (1977) \\
\hline
\end{tabular}

tropopause requires a tropopause temperature increase of $15^{\circ} \mathrm{K}$ (Visconti, 1977). It does not appear that the tropopause temperature is strongly affected by even large variations in $\mathrm{O}_{3}$ (Manabe and Strickler, 1964). To determine the sensitivity of evolving $\mathrm{O}_{3}$ to the choice of a $\mathrm{H}_{2} \mathrm{O}$ vapor profile, we have performed calculations for the present atmospheric $\mathrm{H}_{2} \mathrm{O}$ vapor mixing ratio and for $\mathrm{H}_{2} \mathrm{O}$ vapor profiles equal to $\frac{1}{10}$ and 10 times the present $\mathrm{H}_{2} \mathrm{O}$ vapor profile of London and Park (1974). Since it is beyond the scope of this study to evaluate the eddy diffusion coefficient profile of the paleoatmosphere (there is some debate in the literature concerning the eddy diffusion profile in the present atmosphere), we have used the profile of McElroy et al. (1974) in all of the calculations presented here.
Another specified input parameter is the temperature profile of the paleoatmosphere. Walker (1977) concluded that in the absence of $\mathrm{O}_{3}$, the paleoatmosphere had a troposphere much like the present one and a more or less isothermal stratosphere and mesosphere. Following the procedure of Ratner and Walker (1972), we did not attempt to evaluate temperature profiles in the stratosphere and mesosphere as $\mathrm{O}_{2}$ and $\mathrm{O}_{3}$ built up to present levels. Instead, we used two limiting cases. We used the temperature profile of the U.S. Standard Atmosphere (midlatitude spring/fall temperature profile) for oxygen levels equal to or greater than $10^{-1}$ of the present atmospheric level (PAL) of $\mathrm{O}_{2}$ and a "primordial" temperature profile for $\mathrm{O}_{2}$ levels less than $10^{-1} \mathrm{PAL}$. The "primordial" temperature linearly de- 
creases from the tropopause $(15 \mathrm{~km})$ to the mesopause $(90 \mathrm{~km})$, resulting in an almost isothermal stratosphere. As noted by Ratner and Walker (1972), the effectiveness of $\mathrm{O}_{3}$ absorption in producing a stratospheric temperature increase becomes smaller as the $\mathrm{O}_{3}$ layer moves down to higher pressure levels and is negligibly small for $\mathrm{O}_{3}$ density profiles corresponding to $\mathrm{O}_{2} \leq 10^{-1}$ PAL. These changes in stratopause temperature affect only the high-altitude $\mathrm{O}_{3}$ profile. The effect of the two temperature profiles on the evolution of total $\mathrm{O}_{3}$ will be discussed.

While we are fully aware of the limitations of one-dimensional photochemical models in trying to describe the threedimensional atmosphere, especially in light of the fact that the dominant atmospheric motions are horizontal, not vertical, we believe for the following reasons that a onedimensional model is an appropriate tool in our study: (1) the chemical evolution of the atmosphere can adequately be studied with a one-dimensional photochemical model, and (2) our lack of knowledge of motions and dynamics of the paleoatmosphere precludes a multidimensional study at the present time.

\section{RESULTS}

The Evolution of $\mathrm{O}_{3}$

The vertical distribution of $\mathrm{O}_{3}$ as $\mathrm{O}_{2}$ evolved from $10^{-4}$ to $1 \mathrm{PAL}$ and for an $\mathrm{O}_{2}$ level of 2 PAL for $30^{\circ}$ latitude and equinoctial conditions is shown in Fig. 1. Berkner and Marshall (1965) have suggested that atmospheric $\mathrm{O}_{2}$ levels may have exceeded 1 PAL before the present atmospheric level was achieved. We see that as the $\mathrm{O}_{2}$ level increased from $10^{-4}$ to $1 \mathrm{PAL}$, the height of the $\mathrm{O}_{3}$ peak moved from about 5 to about 25 $\mathrm{km}$. Our calculations indicate that maximum $\mathrm{O}_{3}$ densities at the surface and through the troposphere were achieved for an $\mathrm{O}_{2}$ level of $10^{-1}$ PAL. We calculate surface and tropospheric $\mathrm{O}_{3}$ densities of about $5 \times 10^{12}$ $\mathrm{cm}^{-3}$ for an $\mathrm{O}_{2}$ level of $10^{-1}$ PAL compared to densities of about $5 \times 10^{11} \mathrm{~cm}^{-3}$ in the present atmosphere.

The large surface and tropospheric $\mathrm{O}_{3}$ densities (about $5 \times 10^{12} \mathrm{~cm}^{-3}$ ) in the paleoatmosphere found in this study were not found in the previous studies. Ratner and Walker (1972) reported maximum surface $\mathrm{O}_{3}$ densities of about $1 \times 10^{12} \mathrm{~cm}^{-3}$ based on their calculations using the Chapman reactions. Hesstvedt et al. (1974) found

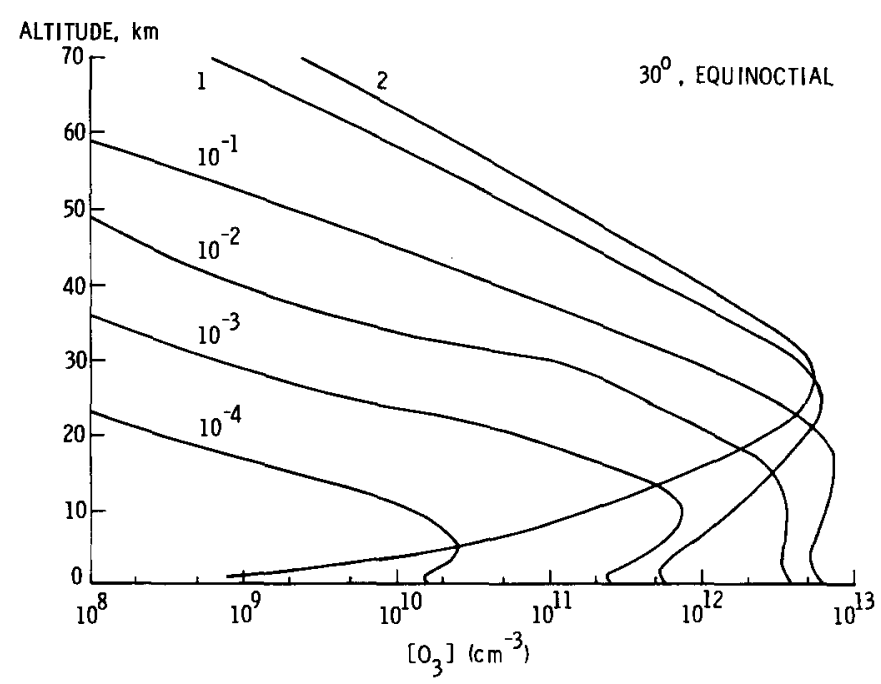

FIG. 1. The vertical distribution of $\mathrm{O}_{3}$ as a function of atmospheric $\mathrm{O}_{2}$ level. 
maximum surface $\mathrm{O}_{3}$ densities of less than $3 \times 10^{10} \mathrm{~cm}^{-3}$ for calculations assuming photochemical equilibrium (no transport) and found maximum surface $\mathrm{O}_{3}$ of about $7 \times 10^{11} \mathrm{~cm}^{-3}$ with the identical chemistry, but including vertical eddy transport. Blake and Carver (1977), assuming photochemical equilibrium in their study, reported maximum surface $\mathrm{O}_{3}$ densities of $2 \times 10^{12} \mathrm{~cm}^{-3}$ for the present atmosphere and smaller surface $\mathrm{O}_{3}$ levels for reduced $\mathrm{O}_{2}$ levels. The enhanced surface and tropospheric $\mathrm{O}_{3}$ densities calculated in our study are due in part to the inclusion of vertical eddy diffusion. The importance of vertical eddy transport on the distribution of $\mathrm{O}_{3}$, particularly below the $\mathrm{O}_{3}$ peak, has been discussed by Nicolet (1975). The importance of vertical eddy transport is also clearly seen in the calculations of Hesstvedt et al. (1974). Using identical chemical schemes, they reported an increase in surface $\mathrm{O}_{3}$ of more than 2 orders of magnitude for an $\mathrm{O}_{2}$ level of $10^{-1}$ PAL when vertical eddy transport was included in their calculations compared to their photochemical equilibrium calculations (no transport).

Of all tropospheric species, $\mathrm{O}_{3}$ comes closest to being naturally present at toxic levels (Chameides and Walker, 1975). Many varieties of plant life are extensively damaged when exposed to $\mathrm{O}_{3}$ concentrations only two or three times greater than the present average ambient concentrations. Chameides and Walker (1975) examined the possible variation of tropospheric $\mathrm{O}_{3}$ over geological time. They considered how changes in the $\mathrm{CH}_{4}$ production rate over geological time would affect the production of $\mathrm{O}_{3}$, and concluded that a tenfold increase in the $\mathrm{CH}_{4}$ production rate would cause a fourfold increase in the tropospheric concentration of $\mathrm{O}_{3}$ for the present level of $\mathrm{O}_{2}$. Our calculations indicate much larger tropospheric levels of $\mathrm{O}_{3}$ than calculated by Chameides and Walker, corresponding to an $\mathrm{O}_{2}$ level of $10^{-1} \mathrm{PAL}$. The toxic effects of these enhanced levels of tropospheric $\mathrm{O}_{3}$ may have had significant adverse effects on both animal and plant life.
The evolution of the total $\mathrm{O}_{3}$ column above the Earth's surface as a function of $\mathrm{O}_{2}$ level is shown in Fig. 2. The calculation of Berkner and Marshall (1965) is shown as the broken line curve 1 , and our calculation for $30^{\circ}$ latitude and equinoctial conditions is shown as the solid line curve 2 . The maximum in total $\mathrm{O}_{3}$ column for an $\mathrm{O}_{2}$ level of $10^{-1} \mathrm{PAL}$, which is contrary to the Berkner and Marshall results, was first pointed out by Ratner and Walker and later confirmed by Blake and Carver. The $\mathrm{O}_{3}$ maximum for an $\mathrm{O}_{2}$ level of $10^{-1}$ PAL resulted from the deeper penetration of solar ultraviolet radiation responsible for the production of $\mathrm{O}$ via the photodissociation of $\mathrm{O}_{2}$. The enhanced number of third bodies $(M)$ at the lower altitude favored the more efficient formation of $\mathrm{O}_{3}$ via the three-body reaction: $\mathrm{O}+\mathrm{O}_{2}+$ $\mathrm{M} \rightarrow \mathrm{O}_{3}+\mathrm{M}$. Solar radiation $\leq 242 \mathrm{~nm}$ is responsible for the photolysis of $\mathrm{O}_{2}$ and the production of $\mathrm{O}$, and hence $\mathrm{O}_{3}$, via the three-body recombination, while solar radi-

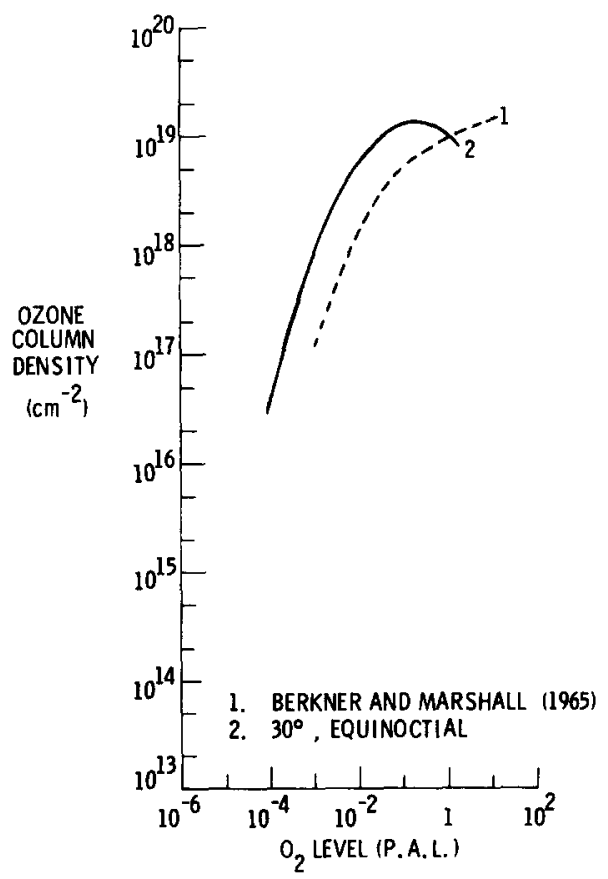

FIG. 2. The total $\mathrm{O}_{3}$ column above the Earth's surface as a function of atmospheric $\mathrm{O}_{2}$ level: comparison of results of Berkner and Marshall (1965) with the present study. Curve 1 is from Berkner and Marshall; curve 2 is for $30^{\circ}$ latitude, equinoctial conditions. 
ation $<1100 \mathrm{~nm}$ is responsible for the photolytic destruction of $\mathrm{O}_{3}$. For an $\mathrm{O}_{2}$ level of $10^{-1} \mathrm{PAL}$, the increased production of $\mathrm{O}_{3}$ resulting from the enhanced penetration of solar ultraviolet radiation is not accompanied by a corresponding increase in the solar radiation responsible for the photolytic loss of $\mathrm{O}_{3}$ and hence $\mathrm{O}_{3}$ maximized. For $\mathrm{O}_{2}$ levels less than $10^{-1}$ PAL, the photolytic destruction of $\mathrm{O}_{3}$ exceeded the production of $\mathrm{O}_{3}$ via the photolysis of $\mathrm{O}_{2}$, and $\mathrm{O}_{3}$ decreased with decreasing $\mathrm{O}_{2}$ level.

The deeper penetration of solar ultraviolet radiation in the $\mathrm{O}_{2}$-deficient paleoatmosphere resulted in the efficient photolysis of $\mathrm{O}_{2}$ and $\mathrm{O}_{3}$. The vertical profile of the photodissociation rate constant of $\mathrm{J} 3$ $\left(\mathrm{O}_{2}: 205-242 \mathrm{~nm}\right)$ for $\mathrm{O}_{2}$ levels ranging from $10^{-4}$ to 2 PAL is shown in Fig. 3. We see that at $15 \mathrm{~km}$, the photolysis rate constant of $\mathrm{O}_{2}$ increased more than 6 orders of magnitude as $\mathrm{O}_{2}$ was decreased from 1 to $10^{-4}$ PAL.

The photodissociation of $\mathrm{O}_{3}$ was divided into three spectral intervals depending on the photolytic products, as shown in Table I: J4 (110-310 nm), J5 (310-360 nm), and J6 $(360-735 \mathrm{~nm})$. The value of J6 was found to be constant (about $1.8 \times 10^{-4} \mathrm{sec}^{-1}$ ) at all altitudes for all $\mathrm{O}_{2}$ levels. The surface value of J5 was found to increase from about
$2 \times 10^{-5} \mathrm{sec}^{-1}$ for an $\mathrm{O}_{2}$ level of $10^{-1} \mathrm{PAL}$ to a value of about $7 \times 10^{-5} \mathrm{sec}^{-1}$ for an $\mathrm{O}_{2}$ level of $10^{-4} \mathrm{PAL}$. The largest increase in the $\mathrm{O}_{3}$ photodissociation rate constant was found for $\mathrm{J} 4$, where the surface value increased from about $5 \times 10^{-7} \mathrm{sec}^{-1}$ for an $\mathrm{O}_{2}$ level of $10^{-1}$ PAL to about $3 \times 10^{-3} \mathrm{sec}^{-1}$ for an $\mathrm{O}_{2}$ level of $10^{-4} \mathrm{PAL}$. The effect of $\mathrm{O}_{2}$ and $\mathrm{O}_{3}$ for $\mathrm{O}_{2}$ levels ranging from $10^{-4}$ to 2 PAL on the vertical distribution of $\mathrm{J} 4$ can be seen in Fig. 4.

For all of our $\mathrm{O}_{3}$ calculations, we have assumed a zero flux of $\mathrm{O}_{3}$ into the surface. Any nonzero flux condition requires knowledge of the composition and the surface chemistry at the Earth's surface, as well as knowledge of the land vs water distribution of the early Earth. An identical zero flux assumption was made by Liu and Donahue (1976) in their study of the $\mathrm{O}_{3}$ budget of the Martian atmosphere (in which they calculated $\mathrm{O}_{3}$ densities at the Martian surface not unlike those that we find for the $\mathrm{O}_{2}$-deficient paleoatmosphere). Liu and Donahue showed that for the other extreme assumption, i.e., if every $\mathrm{O}_{3}$ molecule striking the surface is lost to the surface, then the total $\mathrm{O}_{3}$ column is only decreased by about $50 \%$. Clearly, a surface flux value between the two extreme assumptions will result in less than a $50 \%$ decrease in the total $\mathrm{O}_{3}$ column.

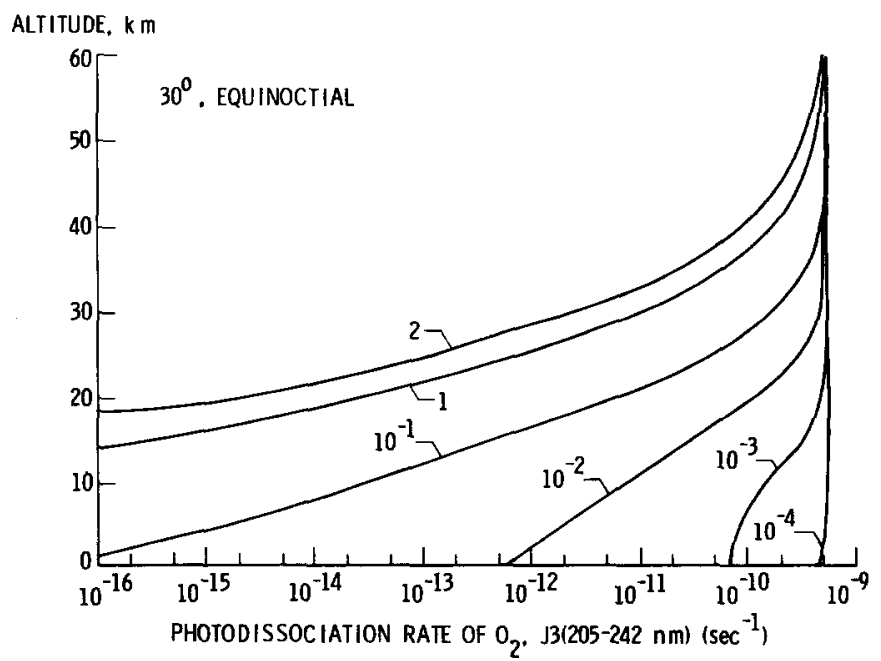

Fig. 3. The vertical distribution of photodissociation rate constant of $\mathrm{J} 3\left(\mathrm{O}_{2}: 205-242 \mathrm{~nm}\right)$ as a function of atmospheric $\mathrm{O}_{2}$ level. 


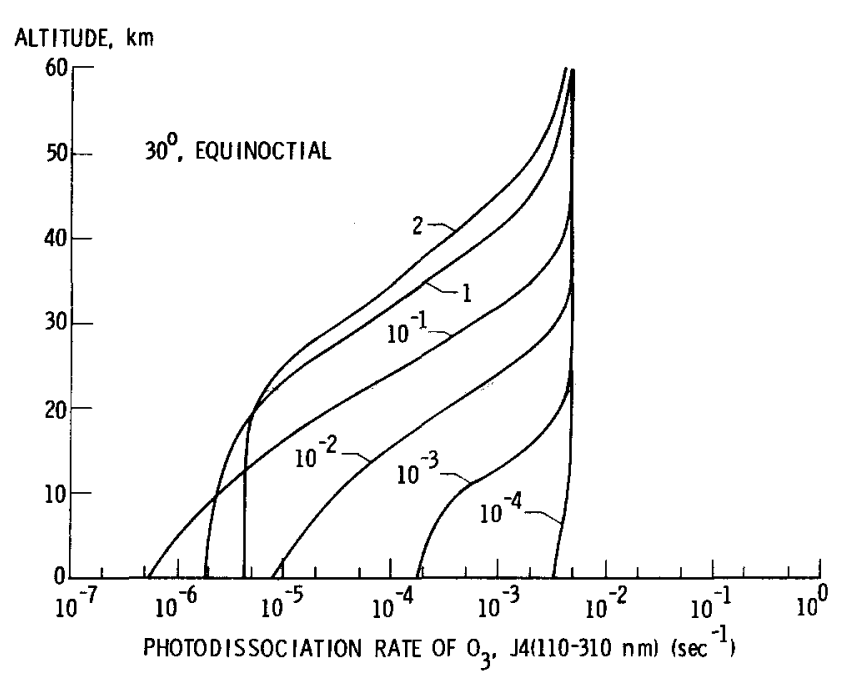

F1G. 4. The vertical distribution of photodissociation rate constant of $\mathrm{J} 4\left(\mathrm{O}_{3}: 110-310 \mathrm{~nm}\right)$ as a function of atmospheric $\mathrm{O}_{2}$ level.

Due to the many uncertainties associated with the choice of a nonzero flux condition and the results of Liu and Donahue, we believe that the choice of the zero flux is a reasonable one in our calculations.

We have also examined the sensitivity of the total $\mathrm{O}_{3}$ column to variations in the assumed model input parameters $\left(\mathrm{NO}_{x}, \mathrm{H}_{2} \mathrm{O}\right.$, and $\mathrm{K}_{z}$ ). For reduced levels of $\mathrm{NO}_{x}$ (onetenth of the present atmospheric level), the total $\mathrm{O}_{3}$ column was found to increase by 15,30 , and $100 \%$ for $\mathrm{O}_{2}$ levels of $10^{-1}, 10^{-2}$, and $10^{-3}$ PAL, respectively. For a reduced $\mathrm{H}_{2} \mathrm{O}$ vapor profile (one-tenth of the present atmospheric $\mathrm{H}_{2} \mathrm{O}$ vapor mixing ratio profile), the total $\mathrm{O}_{3}$ column was found to increase by 3,5 , and $40 \%$ for $\mathrm{O}_{2}$ levels of $10^{-1}, 10^{-2}$, and $10^{-3} \mathrm{PAL}$, respectively. For an enhanced $\mathrm{H}_{2} \mathrm{O}$ vapor profile $(10 \times \mathrm{PAL})$, the total $\mathrm{O}_{3}$ column was found to decrease by 5,25 , and $50 \%$ for $\mathrm{O}_{2}$ levels of $10^{-1}, 10^{-2}$, and $10^{-3} \mathrm{PAL}$, respectively. For an increased $\mathrm{K}_{z}$ profile [ 10 times the standard profile of McElroy et al. (1974)], the total $\mathrm{O}_{3}$ column was found to increase by about $25 \%$ for an $\mathrm{O}_{2}$ level of $10^{-1}$ PAL. No significant changes in the total $\mathrm{O}_{3}$ column were found for the $10 \mathrm{~K}_{z}$ profile for $\mathrm{O}_{2}$ levels less than $10^{-1}$ PAL. Similarly, no significant changes in the total $\mathrm{O}_{3}$ column were found for a $\frac{1}{10}$
$\mathrm{K}_{z}$ profile for all reduced levels of $\mathrm{O}_{2}$. These calculations indicate that the total $\mathrm{O}_{3}$ column in the $\mathrm{O}_{2}$-deficient paleoatmosphere was more sensitive to the $\mathrm{NO}_{x}$ level than to the $\mathrm{H}_{2} \mathrm{O}$ vapor level. However, as discussed in the following section, $\mathrm{N}_{2} \mathrm{O}$ (even at present atmospheric levels) was not an important source of $\mathrm{NO}_{x}$ in the $\mathrm{O}_{2}$-deficient paleoatmosphere. In addition, it appears that cosmic rays and solar proton events were not important sources of $\mathrm{NO}_{x}$ in the $\mathrm{O}_{2}$-deficient paleoatmosphere (Blake and Carver, 1977).

Our calculations suggest the following scenario for the factors that controlled the evolution of $\mathrm{O}_{3}$ in the $\mathrm{O}_{2}$-deficient paleoatmosphere. For $\mathrm{O}_{2}$ levels ranging from $10^{-4}$ to $10^{-2} \mathrm{PAL}$, the evolution of $\mathrm{O}_{3}$ was primarily controlled by $\mathrm{HO}_{x}$ chemistry. Once the $\mathrm{O}_{2}$ level reached $10^{-1}$ PAL, $\mathrm{N}_{2} \mathrm{O}$ was no longer photolytically lost and became a significant source of $\mathrm{NO}_{x}$. At this point, $\mathrm{NO}_{x}$ replaced $\mathrm{HO}_{x}$ as the major controller of the total $\mathrm{O}_{3}$ column.

\section{The Evolution of Nitrogen and Hydrogen Species}

In the present atmosphere, $\mathrm{N}_{2} \mathrm{O}$ is destroyed via photolysis yielding $\mathrm{N}_{2}+\mathrm{O}\left({ }^{1} \mathrm{D}\right)$ and via oxidation by $O\left({ }^{1} \mathrm{D}\right)$ yielding 2 NO. 
This production of NO is the dominant source of stratospheric $\mathrm{NO}_{x}$. Our calculations indicate that for reduced levels of $\mathrm{O}_{2}$ and corresponding $\mathrm{O}_{3}$ levels, the photolytic destruction of $\mathrm{N}_{2} \mathrm{O}$ becomes extremely efficient below $20 \mathrm{~km}$, thereby reducing the main source of stratospheric $\mathrm{NO}_{x}$. The combined effect of $\mathrm{O}_{2}$ and $\mathrm{O}_{3}$ levels on the photodissociation rate of $\mathrm{N}_{2} \mathrm{O}(\mathrm{J} 8)$, which controls the photolytic destruction of $\mathrm{N}_{2} \mathrm{O}$, at the expense of $\mathrm{NO}$ formation, can be seen in Fig. 5. The fact that the surface and lower tropospheric values of $\mathrm{J}\left(\mathrm{N}_{2} \mathrm{O}\right)$ for an $\mathrm{O}_{2}$ level of $10^{-1}$ PAL are slightly less than the values for an $\mathrm{O}_{2}$ level of $1 \mathrm{PAL}$ results from the fact that total atmospheric $\mathrm{O}_{3}$ maximizes for the $10^{-1}$ PAL case. Inspection of Fig. 5 shows that in the present atmosphere, the photodissociation rate constant of $\mathrm{N}_{2} \mathrm{O}$ is about $10^{-7} \mathrm{sec}^{-1}$ at about 35 $\mathrm{km}$. For an $\mathrm{O}_{2}$ level of $10^{-1}$ PAL this same photodissociation rate constant is achieved at about $25 \mathrm{~km}$, at about $15 \mathrm{~km}$ for an $\mathrm{O}_{2}$ level of $10^{-2}$ PAL, and at the surface for an $\mathrm{O}_{2}$ level of $10^{-3} \mathrm{PAL}$. The profile of $\mathrm{N}_{2} \mathrm{O}$ mixing ratio for various $\mathrm{O}_{2}$ levels is shown in Fig. 6. Due to our lack of knowledge concerning the $\mathrm{N}_{2} \mathrm{O}$ surface mixing ratio appropriate for the primordial atmosphere, we have used the present surface mixing ratio

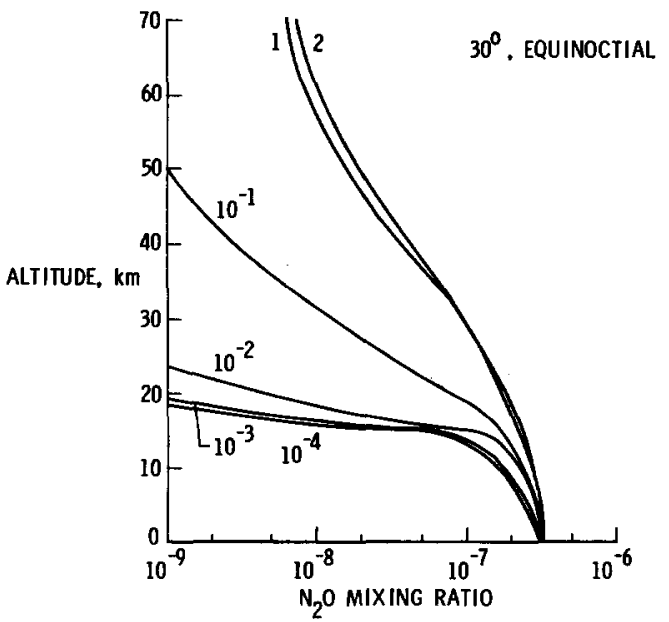

FIG. 6. The vertical distribution of the $\mathrm{N}_{2} \mathrm{O}$ mixing ratio as a function of atmospheric $\mathrm{O}_{2}$ level. For all calculations the lower boundary mixing ratio was $3.2 \times 10^{-7}$.

$\left(3.2 \times 10^{-7}\right)$ as the lower boundary for all of the calculations shown in Fig. 6. Inspection of Fig. 6 shows that comparable $\mathrm{N}_{2} \mathrm{O}$ mixing ratios $\left(10^{-8}\right)$ are found above $55 \mathrm{~km}$ in the present atmosphere and below $20 \mathrm{~km}$ for an $\mathrm{O}_{2}$ level of $10^{-2}$ PAL.

This is the first study of the evolution of $\mathrm{O}_{3}$ to include $\mathrm{N}_{2} \mathrm{O}$, the main source of stratospheric $\mathrm{NO}_{x}$, which is the dominant $\mathrm{O}_{3}$ destruction species in the present atmo-

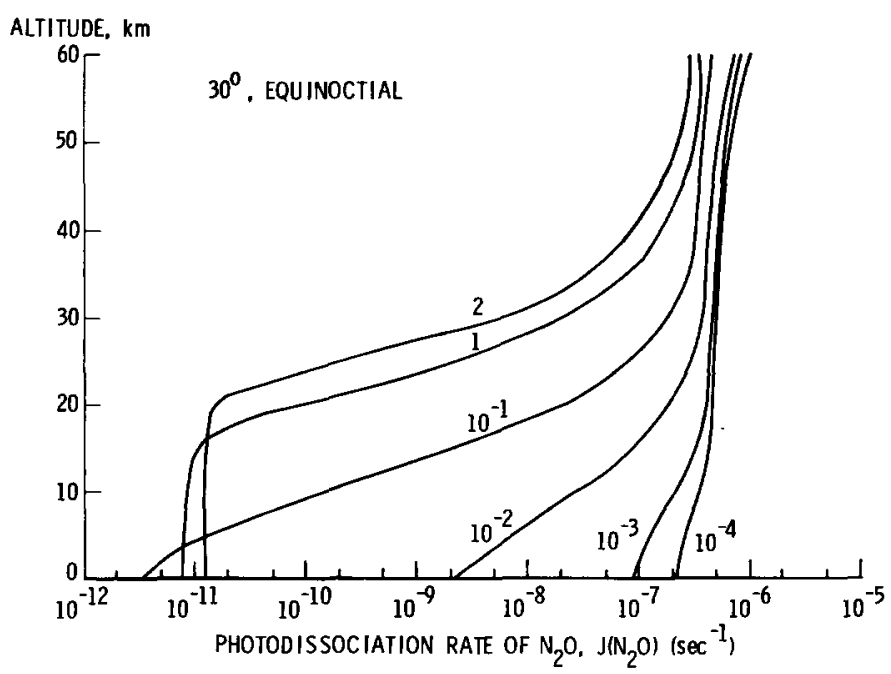

FIG. 5. The vertical distribution of the photodissociation rate constant of $\mathrm{N}_{2} \mathrm{O}(\mathrm{J8})$ as a function of atmospheric $\mathrm{O}_{2}$ level. 
sphere. In $\mathrm{O}_{2}$-deficient atmospheres, we have found that $\mathrm{N}_{2} \mathrm{O}$ (even at present atmospheric mixing ratios) produces much less $\mathrm{NO}_{x}$ than it does in the present atmosphere. In addition, we found that $\mathrm{NO}_{x}$ was not an important $\mathrm{O}_{3}$ destruction species in $\mathrm{O}_{2}$-deficient atmospheres. We found that the rapid photolytic destruction of $\mathrm{N}_{2} \mathrm{O}$ resulted in negligible production of $\mathrm{NO}_{x}$ via the oxidation of $\mathrm{N}_{2} \mathrm{O}$ which, in turn, relegated $\mathrm{NO}_{x}$ catalytic destruction of $\mathrm{O}_{3}$, perhaps the major $\mathrm{O}_{3}$ destruction process in the present atmosphere (Johnston, 1975), to a negligible role for reduced $\mathrm{O}_{2}$ levels. In past studies $\mathrm{N}_{2} \mathrm{O}$ was neglected due to biological considerations because it was assumed that nitrogen fixation and the subsequent dentrification of $\mathrm{N}_{2} \mathrm{O}$ by soil bacteria was not important in the Earth's early history. Now, based on aeronomical considerations, we have found that $\mathrm{N}_{2} \mathrm{O}$ was not important in controlling early $\mathrm{O}_{3}$ levels, regardless of the level of bacterial dentrification of $\mathrm{N}_{2} \mathrm{O}$.

The effects of the $\mathrm{O}_{2}$ and $\mathrm{O}_{3}$ levels on the vertical distribution of the odd nitrogen species ( $\mathrm{NO}+\mathrm{NO}_{2}+\mathrm{HNO}_{3}$ ) for the same surface mixing ratio $\left(3.0 \times 10^{-9}\right)$ are shown in Fig. 7. At a given altitude, the number density of the odd nitrogen species was found to decrease with decreasing $\mathrm{O}_{2}$ level. This is opposite from the effect we found for the hydrogen species $\left(\mathrm{H}, \mathrm{OH}\right.$, and $\left.\mathrm{HO}_{2}\right)$ where, at a given altitude, the number density was found to increase with decreasing $\mathrm{O}_{2}$ and $\mathrm{O}_{3}$ levels.

The efficient transmission of solar uv into the lower stratosphere and troposphere, which results in the rapid photolytic loss of $\mathrm{O}_{3}$ and $\mathrm{N}_{2} \mathrm{O}$ [and production of $\mathrm{O}\left({ }^{1} \mathrm{D}\right)$ ], at the same time results in the extremely efficient production of $\mathrm{OH}$ via the photolysis of $\mathrm{H}_{2} \mathrm{O}$ and the oxidation of $\mathrm{H}_{2} \mathrm{O}$ by $\mathrm{O}\left({ }^{1} \mathrm{D}\right)$. The combined effect of $\mathrm{O}_{2}$ and $\mathrm{O}_{3}$ on the photodissociation rate constant of $\mathrm{H}_{2} \mathrm{O}(\mathrm{J} 7)$, which results in the photolytic production of $\mathrm{OH}$, can be seen in Fig. 8. Inspection of Fig. 8 shows that in the present atmosphere, the photodissociation rate constant of $\mathrm{H}_{2} \mathrm{O}$ is about $10^{-9} \mathrm{sec}^{-1}$ at about $45 \mathrm{~km}$. For an $\mathrm{O}_{2}$ level of $10^{-1}$ PAL, this photodissociation rate constant is achieved at about $30 \mathrm{~km}$, at about $17 \mathrm{~km}$ for an $\mathrm{O}_{2}$ level of about $10^{-2} \mathrm{PAL}$, and at about $10 \mathrm{~km}$ for an $\mathrm{O}_{2}$ level of $10^{-3} \mathrm{PAL}$. The profile of $\mathrm{OH}$ resulting from the photolysis of $\mathrm{H}_{2} \mathrm{O}$ and from the reaction of $\mathrm{O}\left({ }^{1} \mathrm{D}\right)$ with $\mathrm{H}_{2} \mathrm{O}$ for various $\mathrm{O}_{2}$ levels is shown in Fig. 9. Inspection of Fig. 9 shows that $\mathrm{OH}$ concentrations in

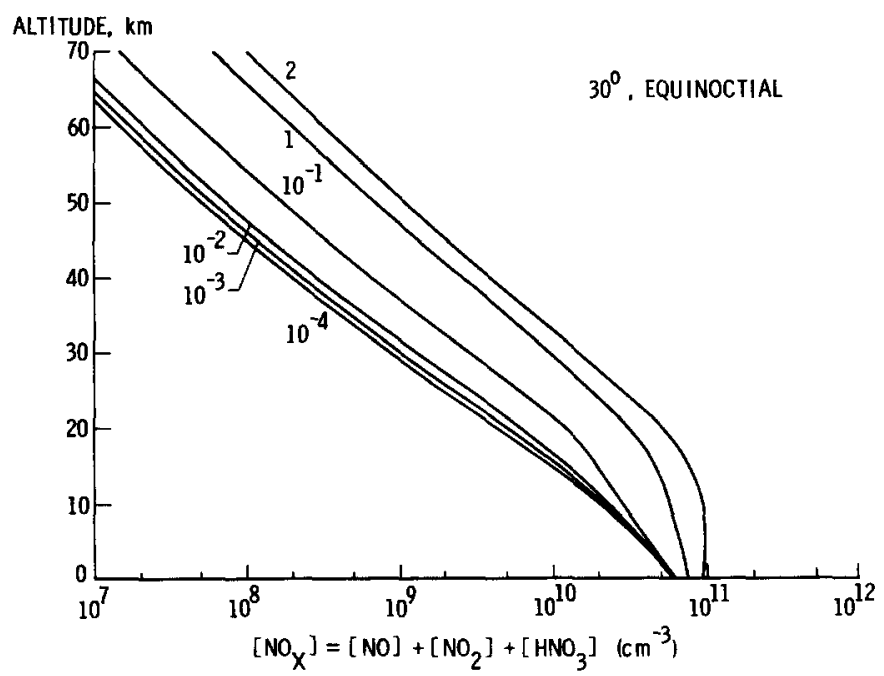

FIG. 7. The vertical distribution of $\mathrm{NO}_{x}\left(\mathrm{NO}+\mathrm{NO}_{2}+\mathrm{HNO}_{3}\right)$ as a function of atmospheric $\mathrm{O}_{2}$ level. For all calculations the lower boundary mixing ratio was $3.0 \times 10^{-9}$. 


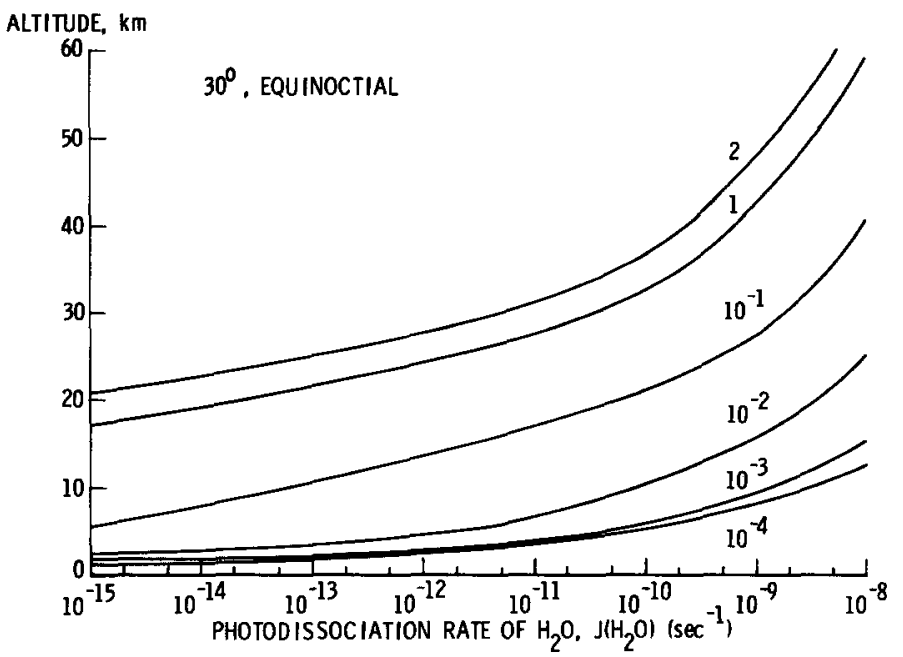

FIG. 8. The vertical distribution of the photodissociation rate constant of $\mathrm{H}_{2} \mathrm{O}(\mathrm{J} 7)$ as a function of atmospheric $\mathrm{O}_{2}$ level.

the troposphere and lower stratosphere increased by about 4 orders of magnitude as the $\mathrm{O}_{2}$ level was reduced from 1 to $10^{-4}$ PAL.

The increase (decrease) in total $\mathrm{O}_{3}$ resulting from a decrease (increase) in the assumed $\mathrm{H}_{2} \mathrm{O}$ vapor profile previously discussed is a direct consequence of decreased (increased) formation of $\mathrm{OH}$ via the photolysis and oxidation of $\mathrm{H}_{2} \mathrm{O}$. The percentage increase (decrease) in $\mathrm{OH}$ density results in an almost identical percentage decrease (increase) in $\mathrm{O}_{3}$ density beginning about $10 \mathrm{~km}$ above the $\mathrm{O}_{3}$ peak for all reduced $\mathrm{O}_{2}$ levels.

\section{CONCLUSIONS}

Some of the new findings of our investigation are:

(1) Surface and tropospheric $\mathrm{O}_{3}$ densities of the paleoatmosphere exceeded those of the present atmosphere by about a factor of

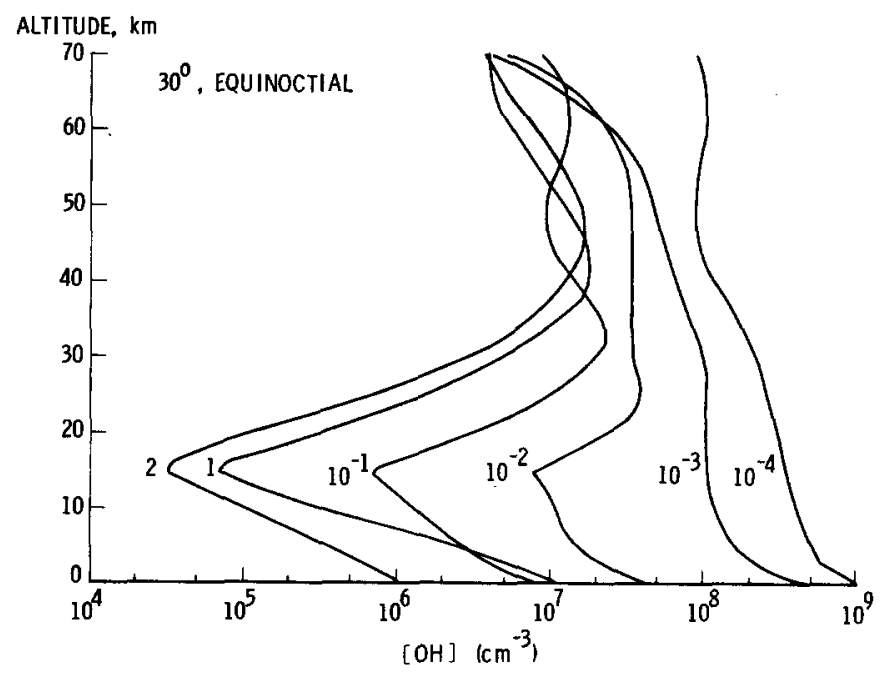

FIG. 9. The vertical distribution of $\mathrm{OH}$ as a function of atmospheric $\mathrm{O}_{2}$ level. 
10. Our calculations indicate maximum surface and tropospheric $\mathrm{O}_{3}$ densities of about $5 \times 10^{12} \mathrm{~cm}^{-3}$ for an $\mathrm{O}_{2}$ level of $10^{-1} \mathrm{PAL}$, compared to surface $\mathrm{O}_{3}$ densities of $5 \times 10^{11} \mathrm{~cm}^{-3}$ in the present atmosphere.

(2) Surface and tropospheric $\mathrm{OH}$ densities of the paleoatmosphere exceeded those of the present atmosphere by several orders of magnitude. Maximum surface and tropospheric $\mathrm{OH}$ densities approached $10^{9}$ $\mathrm{cm}^{-3}$ for an $\mathrm{O}_{2}$ level of $10^{-4} \mathrm{PAL}$, compared to surface and lower tropospheric $\mathrm{OH}$ densities of about $10^{6} \mathrm{~cm}^{-3}$ in the present atmosphere.

(3) In the $\mathrm{O}_{2}$-deficient paleoatmosphere, $\mathrm{N}_{2} \mathrm{O}$ (even at present atmospheric levels) produces much less $\mathrm{NO}_{x}$ than it does in the present atmosphere.

(4) The evolution of $\mathrm{O}_{3}$ in the paleoatmosphere was controlled by the efficient transmission of solar ultraviolet radiation through the lower stratosphere and troposphere. The enhanced level of ultraviolet radiation was responsible for the photolytic destruction of $\mathrm{O}_{3}$ and $\mathrm{N}_{2} \mathrm{O}$ and the enhanced production of the hydrogen species.

(5) The evolution of total $\mathrm{O}_{3}$ as a function of $\mathrm{O}_{2}$ level was fairly insensitive to the assumed model input parameters $\left(\mathrm{N}_{2} \mathrm{O}\right.$ level and temperature and $\mathrm{H}_{2} \mathrm{O}$ vapor profiles).

We also verified the results of the earlier studies of Ratner and Walker, and Blake and Carver that $\mathrm{O}_{3}$ evolved to a greater level for a given $\mathrm{O}_{2}$ level than indicated by Berkner and Marshall; or alternatively, that $\mathrm{O}_{3}$ evolved earlier in the Earth's history than suggested by Berkner and Marshall. The earlier rise of $\mathrm{O}_{3}$ in the history of $\mathrm{O}_{2}$ evolution undoubtedly had important implications for biological evolution on our planet. The precise implications must wait until we have a better understanding of the exact chronology for the evolution of $\mathrm{O}_{2}$.

\section{APPENDIX: DESCRIPTION OF PHOTOCHEMICAL MODEL}

The form of the time-independent or steady-state species continuity equation which was used to calculate the vertical distribution of the transported species $\mathrm{O}_{3}$, $\mathrm{N}_{2} \mathrm{O}$, and $\mathrm{NO}_{x}$ is

$$
\partial \phi_{i} / \partial z=Q_{i}\left(n_{j}\right)-L_{i}\left(n_{j}\right) M f_{i},
$$

where $f_{i}$ is the volume mixing ratio of the $i$ th species, $\phi_{i}$ is the vertical flux (molecules $\left.\mathrm{cm}^{-2} \mathrm{sec}^{-1}\right)$ of the $i$ th species, $Q_{i}\left(n_{j}\right)$ are the chemical production terms and $L_{i}\left(n_{j}\right) M f_{i}$ are the chemical loss terms of the ith species. The volume mixing ratio $f_{i}$ is related to $n_{i}$, the number density of the $i$ th species (molecules $\mathrm{cm}^{-3}$ ) by

$$
f_{i}=n_{i} / M,
$$

where $M$ is the total number density (molecules $\mathrm{cm}^{-3}$ ).

The vertical flux of the $i$ th species $\phi_{i}$ can be expressed as

$$
\phi_{i}=-K_{z} M\left[\left(\partial f_{i} / \partial z\right)\right],
$$

where $K_{z}$ is the vertical eddy diffusion coefficient $\left(\mathrm{cm}^{2} \mathrm{sec}^{-1}\right)$. Substituting Eq. (3) into Eq. (1) we get

$$
\begin{aligned}
(\partial / \partial z)\left[K_{z} M\left(\partial f_{i} / \partial z\right)\right] & \\
& =-Q_{i}\left(n_{j}\right)+L_{i}\left(n_{j}\right) M f_{i} .
\end{aligned}
$$

The vertical distribution of the rapidly reacting atmospheric species $\mathrm{O}, \mathrm{O}\left({ }^{1} \mathrm{D}\right), \mathrm{H}$, $\mathrm{OH}, \mathrm{HO}_{2}$, and $\mathrm{H}_{2} \mathrm{O}_{2}$ is determined solely by chemistry, which, for these species, is considerably faster than transport. For these species, we can neglect the transport terms of the continuity equation [the left side of Eq. (4)] and equate the chemical production to the chemical loss, and solve for the species mixing ratio $f_{i}$ using the photochemical equilibrium assumption

$$
f_{i}=Q_{i}\left(n_{j}\right) / L_{i}\left(n_{j}\right) M .
$$

$\mathrm{N}_{2} \mathrm{O}$ is produced by soil bacteria during dentrification. The main source of stratospheric $\mathrm{NO}$ is the oxidation of $\mathrm{N}_{2} \mathrm{O}$ by $\mathrm{O}\left({ }^{1} \mathrm{D}\right)$ (Bates and Hays, 1967; Crutzen, 1970; McElroy and McConnell, 1971). Assuming photochemical equilibrium, $O\left({ }^{1} \mathrm{D}\right)$ is calculated by

$$
\left[\mathrm{O}\left({ }^{1} \mathrm{D}\right)\right]=J_{4}\left[\mathrm{O}_{3}\right] / k_{4}[M] .
$$


Most of the $\mathrm{N}_{2} \mathrm{O}$ is simply photolyzed to $\mathrm{N}_{2}$ and $O\left({ }^{1} \mathrm{D}\right)$.

For the $\mathrm{N}_{2} \mathrm{O}$ continuity equation, the chemical loss term $L_{i}\left(n_{j}\right)$ in the general form of the continuity equation in Eq. (4) has the form

$$
L_{i}\left(n_{j}\right)=\left\{J_{8}+\left(k_{5}+k_{6}\right)\left[\mathrm{O}\left({ }^{1} \mathrm{D}\right)\right]\right\} .
$$

The only stratospheric chemical source for $\mathrm{NO}_{x}$ is the oxidation of $\mathrm{N}_{2} \mathrm{O}$. Furthermore, there are no stratospheric chemical sinks for $\mathrm{NO}_{x}$; all reactions simply involve interconversions of species in the $\mathrm{NO}_{x}$ family. Tropospheric rainout of $\mathrm{HNO}_{3}$ is the major atmospheric sink for $\mathrm{NO}_{x}$ resulting in an $\mathrm{NO}_{x}$ surface mixing ratio of about $3 \times 10^{-9}$, an order of magnitude smaller than the stratospheric mixing ratio of $\mathrm{NO}_{x}$. For the $\mathrm{NO}_{x}$ continuity equation, the chemical production term $Q_{i}\left(n_{j}\right)$ in the general form of the continuity equation in $\mathrm{Eq}$. (4) has the form

$$
Q_{i}\left(n_{j}\right)=\left\{2 k_{5}\left[\mathrm{O}\left({ }^{\mathrm{I} D}\right)\right]\right\}\left[\mathrm{N}_{2} \mathrm{O}\right] .
$$

These facts result in a simplified approach to the calculation of the vertical profiles of $\mathrm{NO}, \mathrm{NO}_{2}$, and $\mathrm{HNO}_{3}$, by far the dominant species of $\mathrm{NO}_{x}$ within the stratosphere. The distribution of $\mathrm{NO}_{x}$ is determined using continuity Eq. (4). Next, $\mathrm{NO}_{x}$ is divided among $\mathrm{NO}, \mathrm{NO}_{2}$, and $\mathrm{HNO}_{3}$ by the ratios (Shimazaki and Ogawa, 1974; and Hudson, 1977)

$$
\begin{aligned}
r_{1}= & {[\mathrm{NO}] /\left[\mathrm{NO}_{2}\right] \approx\left\{J_{12}\right.} \\
& \left.+k_{9}[\mathrm{O}]\right\} /\left\{k_{8}\left[\mathrm{O}_{3}\right]+k_{11}\left[\mathrm{HO}_{2}\right]\right\},
\end{aligned}
$$

The vertical distribution of $O$ required in Eqs. (9) and (10) is calculated assuming photochemical equilibrium and given by

$$
\begin{aligned}
{[\mathrm{O}]=} & \left\{2\left(J_{1}+J_{2}+J_{3}\right)\left[\mathrm{O}_{2}\right]\right. \\
+ & \left.\left(J_{4}+J_{5}+J_{6}\right)\left[\mathrm{O}_{3}\right]+J_{12}[\mathrm{NO} 2]\right\} / \\
& \left\{k_{1}\left[\mathrm{O}_{2}\right][M]+k_{2}\left[\mathrm{O}_{3}\right]+k_{17}[\mathrm{OH}]\right. \\
& \left.+k_{20}\left[\mathrm{HO}_{2}\right]+k_{9}\left[\mathrm{NO}_{2}\right]\right\} .
\end{aligned}
$$

Note that the ratios given in Eqs. (9) and and
(10) are determined by species other than nitrogen and nitrogen-oxygen compounds. Unfortunately, such a simplification does not exist in the hydrogen chemistry.

In the case of the hydrogen species there are many nonlinear terms of $\mathrm{H}, \mathrm{OH}, \mathrm{HO}_{2}$, and $\mathrm{H}_{2} \mathrm{O}_{2}$, and they are not necessarily smaller than the linear terms, although some of them are small at particular heights. Hence it is very difficult to specify concentration ratios which would be both simple and applicable to the entire stratosphere. Thus, the scheme used for the $\mathrm{NO}_{x}$ family is not applicable for the hydrogen species. However, in the stratosphere (and troposphere) $\mathrm{H}, \mathrm{OH}, \mathrm{HO}_{2}$, and $\mathrm{H}_{2} \mathrm{O}_{2}$ are in photochemical equilibrium (London and Park, 1974). The vertical profiles of $\mathrm{H}, \mathrm{OH}$, $\mathrm{HO}_{2}$, and $\mathrm{H}_{2} \mathrm{O}_{2}$ can be calculated by the simultaneous solution of Eqs. (12)-(15) assuming photochemical equilibrium (London and Park, 1974)

$$
\begin{array}{r}
{[\mathrm{H}]=\left\{k_{18}[\mathrm{O}][\mathrm{OH}]+J_{7}\left[\mathrm{H}_{2} \mathrm{O}\right]\right\} /} \\
\left\{k_{16}\left[\mathrm{O}_{3}\right]+k_{15}\left[\mathrm{O}_{2}\right][\mathrm{M}]\right\}
\end{array}
$$

$$
\begin{gathered}
{\left[\mathrm{HO}_{2}\right]=\left\{k_{18}\left[\mathrm{O}_{3}\right][\mathrm{OH}]\right.} \\
\left.+k_{24}\left[\mathrm{H}_{2} \mathrm{O}_{2}\right][\mathrm{OH}]+k_{15}[\mathrm{H}]\left[\mathrm{O}_{2}\right][\mathrm{M}]\right\} / \\
\left\{k_{20}[\mathrm{O}]+k_{21}\left[\mathrm{O}_{3}\right]+k_{22}[\mathrm{OH}]\right. \\
\left.\quad+2 k_{23}\left[\mathrm{HO}_{2}\right]+k_{11}[\mathrm{NO}]\right\}
\end{gathered}
$$

$[\mathrm{OH}]=\left(\left\{J_{7}\left[\mathrm{H}_{2} \mathrm{O}\right]+J_{15}\left[\mathrm{H}_{2} \mathrm{O}_{2}\right]\right.\right.$

$$
\left.+k_{14}\left[\mathrm{O}\left({ }^{1} \mathrm{D}\right)\right]\left[\mathrm{H}_{2} \mathrm{O}\right]\right\} /
$$$$
\left\{k_{19}+k_{22}\left[\mathrm{HO}_{2}\right] /[\mathrm{OH}]+k_{23}\left[\mathrm{HO}_{2}\right]^{2} /\right.
$$$$
\left.\left.[\mathrm{OH}]^{2}+k_{13}\left[\mathrm{HNO}_{3}\right] /[\mathrm{OH}]\right\}\right)^{1 / 2} \text {, }
$$

$\left[\mathrm{H}_{2} \mathrm{O}_{2}\right]$

$$
=k_{23}\left[\mathrm{HO}_{2}\right]\left[\mathrm{HO}_{2}\right] / k_{24}[\mathrm{OH}]+J_{13} \text {. }
$$

A continuity equation for stratospheric and mesospheric $\mathrm{O}_{3}$, including the effect of $\mathrm{NO}_{x}$ and $\mathrm{HO}_{x}$ species, can be written with the following $\mathrm{O}_{3}$ chemical production $\left[Q_{i}\left(n_{j}\right)\right]$ and loss $\left[L_{i}\left(n_{j}\right)\right]$ terms expressed as (Nicolet, 1975)

$$
Q_{i}\left(n_{j}\right)=k_{1}[\mathrm{M}]\left[\mathrm{O}_{2}\right][\mathrm{O}]
$$




$$
\begin{aligned}
L_{i}\left(n_{j}\right)= & \left\{J_{4}+J_{5}+J_{6}+k_{2}[\mathrm{O}]\right. \\
+ & k_{8}[\mathrm{NO}]+k_{10}\left[\mathrm{NO}_{2}\right]+k_{16}[\mathrm{H}] \\
& \left.+k_{18}[\mathrm{OH}]+k_{21}\left[\mathrm{HO}_{2}\right]\right\} .
\end{aligned}
$$

For a given level of $\mathrm{O}_{2}$, a "first guess" profile of $\mathrm{O}_{3}$ was calculated using the Chapman scheme, identical to the procedure of Ratner and Walker (1972). The first guess $\mathrm{O}_{3}$ profile was then used to calculate the 13 photodissociation rates shown in Table I. Next, the profiles of $\mathrm{N}_{2} \mathrm{O}$ and $\mathrm{NO}_{x}$ $\left(\mathrm{NO}+\mathrm{NO}_{2}+\mathrm{HNO}_{3}\right)$ were calculated via the continuity equation, using a standard tridiagonal solver, based on the Gaussian elimination method without pivoting (Smith, 1965). The profiles of $\mathrm{H}, \mathrm{OH}, \mathrm{HO}_{2}$, and $\mathrm{H}_{2} \mathrm{O}_{2}$ were next calculated simultaneously using the standard NewtonRaphson method (Smith, 1965). Next, the $\mathrm{O}_{3}$ profile was recalculated via the continuity equation, including the effect of nitrogen and hydrogen species. The new $\mathrm{O}_{3}$ profile was then used to recalculate the photodissociation rates and all of the species profiles. The iterative process continued until the convergence condition (a change in $\mathrm{O}_{3}$ of less than $0.1 \%$ at all altitudes on successive iterations) was achieved.

\section{ACKNOWLEDGMENTS}

It is a pleasure to acknowledge Ms. Kathryn A. Smith of the Langley Research Center for her important contributions and expert support in the numerical and computational aspects of this study. John E. Hogge and John N. Shoosmith of Langley also assisted on various numerical aspects of this investigation. Marvin R. Libson of Integrated Services, Inc. (ISI), Hampton, Virginia, was a continual source of many enlightening discussions, and Fred $M$. Smith of Langley made most constructive comments in the preparation of this manuscript. We would also like to acknowledge the contributions of William R. Kuhn and Herschel Weil (both of the University of Michigan), Richard S. Stolarski (Goddard Space Flight Center), and the continued support provided by Robert $\mathrm{H}$. Tolson and James D. Lawrence, Jr., of Langley during the course of this study.

\section{REFERENCES}

ACKermanN, M. (1971). Ultraviolet solar radiation related to mesospheric processes. In Mesospheric
Models and Related Experiments (G. Fiocco, Ed.), pp. 149-159. Reidel, Dordrecht.

Bates, D. R., AND Hays, P. B. (1967). Atmospheric nitrous oxide. Planet. Space Sci. 15, 189-196.

Berkner, L. V., AND Marshall, L. C. (1965). On the origin and rise of oxygen concentration in the Earth's atmosphere. J. Atmos. Sci. 22, 225-261.

Blake, A. J., and Carver, J. H. (1977). The evolutionary role of atmospheric ozone. J. Atmos. Sci. 34, $720-728$.

Chameides, W., and Walker, J. C. G. (1975). Possible variation of ozone in the troposphere during the course of geologic time. Amer. J. Sci. 275, 737-752.

Crutzen, P. J. (1970). The influence of nitrogen oxides on the atmospheric ozone content. Quart. $J$. Roy. Meteorol. Soc. 96, 320-325.

Dixon, J. K. (1940). The absorption coefficient of nitrogen dioxide in the visible spectrum. J. Chem. Phys. 8, 157-160.

GrigGs, M. (1968). Absorption coefficients of ozone in the ultraviolet and visible regions. J. Chem. Phys. 49, 857-859.

Hall, T. C., and Blacet, F. E. (1952). Separation of the absorption spectra of $\mathrm{NO}_{2}$ and $\mathrm{N}_{2} \mathrm{O}_{4}$ in the range of 2400-5000 $\AA$. J. Chem. Phys. 20, 1745-1749.

HART, M. H. (1978). The evolution of the atmosphere of the Earth. Icarus 33, 23-39.

Hasson, V., and Nicholls, R. W. (1971). Absolute spectral absorption measurements on molecular oxygen from 2640-1920 $\AA$. 2. Continuum Measurements 2430-1920 Å. Proc. Phys. Soc. London At. Molec. Phys. 4, 1789-1997.

Hesstvedt, E., Henriksen, S. E., and HuartarSON, H. (1974). On the development of an aerobic atmosphere. A model experiment. Geophysica Norvegica $31,1-8$.

Hudson, R. D. (1977). Chlorofluoromethanes and the Stratosphere. NASA Reference Publication 1010.

Hudson, R. D., ANd Mahle, S. H. (1972). Photodissociation rates of molecular oxygen in the mesosphere and lower thermosphere. J. Geophys. Res. 77, 2902-2914.

Huie, R. E., Herron, J. T., and Davis, D. D. (1972). Absolute rate constants for the reaction $\mathrm{O}+\mathrm{O}_{2}+M$ $\rightarrow \mathrm{O}_{3}+M$ over the temperature range $200-346^{\circ} \mathrm{K} . J$. Phys. Chem. 76, 2653-2658.

InN, E. C. Y., AND TANAKa, Y. (1953). Absorption coefficients of ozone in the ultraviolet and visible regions. J. Opt. Soc. Amer. 43, 870-873.

JoHNSTON, H. S. (1975). Global ozone balance in the natural stratosphere. Rev. Geophys. Space Phys. 13, 637-649.

Johnston, H. S., AND Graham, R. (1974). Photochemistry of $\mathrm{NO}_{x}$ and $\mathrm{HNO}_{x}$ compounds. Canad. $J$. Chem. 52, 1415-1423.

Johnston, H. S., ANd SElwyN, G. S. (1975). Cross sections for the absorption of near ultraviolet radiation by nitrous oxide $\left(\mathrm{N}_{2} \mathrm{O}\right)$. Geophys. Res. Lett. 2, 549-551. 
Liu, S. C., And Donahue, T. M. (1974). The aeronomy of hydrogen in the atmosphere of the Earth. J. Atmos. Sci. 31, 1118-1136.

Liu, S. C., And Donahue, T. M. (1976). The regulation of hydrogen and oxygen escape from Mars. Icarus 28, 231-246.

London, J., AND PARK, J. H. (1974). The interaction of ozone photochemistry and dynamics in the stratosphere. A three-dimensional atmospheric model. Canad. J. Chem. 52, 1599-1609.

Manabe, S., And Strickler, R. F. (1964). Thermal equilibrium of the atmosphere with a convective adjustment. J. Atmos. Sci. 21, 361-385.

McElroy, M. B., AND MCConNell, J. C. (1971). Nitrous oxide: A natural source of stratospheric NO. J. Atmos. Sci. 28, 1095-1098.

MCElroy, M. B., Wofsy, S. C., Penner, J. E., AND MCConnell, J. C. (1974). atmospheric ozone: Possible impact of stratospheric aviation. J. Atmos. Sci. 31, 287-303.

NaKayama, T., Kitamura, M. Y., and Watanabe, K. (1959). Ionization potential and absorption coefficients of nitrogen dioxide. J. Chem. Phys. 30, 1180-1186.

Nicolet, M. (1975). Stratospheric ozone: An introduction to its study. Rev. Geophys. Space Phys. 13, 593-636.

PAukert, T. T., AND Johnston, H. S. (1972). Spectra and kinetics of the hydroperoxyl free radical in the gas phase. J. Chem. Phys. 56, 2824-2838.

Ratner, N. I., AND Walker, J. C. G. (1972). Atmospheric ozone and the history of life. J. Atmos. Sci. 29, 803-808.

Rundel, D. R. (1977). Determination of diurnal average photodissociation rates. J. Atmos. Sci. 34, 639641.

Schmidt, S. G., Amme, R. C., Murcray, D. G., Goldman, A., AND Bonomo, F. S. (1974). Ul- traviolet absorption by nitric acid vapor. Nature 238, 109.

Schürgers, M., and Welge, K. H. (1968). Absorption Koeffizient von $\mathrm{H}_{2} \mathrm{O}_{2}$ Zwischen 1200 and 2000 Å, Z. Naturforseh. A. 23, 1508-1510.

Shimazaki, T., AND Ogawa, T. (1974). A theoretical model of minor constituent distributions in the stratosphere including diurnal variations. $J$. Geophys. Res. 79, 3411-3423.

SMITH, G. D. (1965). Numerical Solution of Partial Differential Equations. Oxford Univ. Press, London.

Stewart, R. W., AND Hoffert, M. I. (1975). A chemical model of the troposphere and stratosphere. J. Atmos. Sci. 32, 195-210.

The Natural Stratosphere of 1974. CIAP Monograph I. Final report prepared for the Climatic Impact Assessment Program, Dept. of Transportation, Washington, D.C.

U.S. Standard Atmosphere (1962). U.S. Government Printing Office, Washington, D.C.

Visconti, G. (1977). Hydrogen escape in the terrestrial atmosphere at low oxygen levels: A photochemical model. J. Atmos. Sci. 34, 193-204.

WALKer, J. C. G. (1977). Evolution of the Atmosphere. Macmillan Co., New York.

WALKER, J. C. G. (1978). The early history of oxygen and ozone in the atmosphere. Pure Appl. Geophys. 117, 498-512.

WATANaBe, K. (1958). Ultraviolet absorption processes in the upper atmosphere. Advan. Geophys. 5, 153-221.

Watanabe, K., and Zelikoff, M. (1953). Absorption coefficients of water vapor in the vacuum ultraviolet. J. Opt. Soc. Amer. 43, 753-755.

WofsY. S. C. (1976). Interactions of $\mathrm{CH}_{4}$ and $\mathrm{CO}$ in the Earth's atmosphere. Ann. Rev. Earth Planet. Sci. 4, 441-469. 